\title{
The use of remote sensing techniques by Modis (MCD45A1) images using to identify and evaluate burned areas in the metropolitan region of Belo Horizonte- MG, Brazil
}

\author{
Uso de técnicas de sensoriamento remoto utilizando \\ imagens Modis (MCD45A1) para identificação \\ e avaliação de áreas queimadas na Região \\ Metropolitana de Belo Horizonte - MG, Brasil
}

Luiza Cintra Fernandes ${ }^{a}$

Marcelo Antonio Nerob

Plínio Tembac

Marcos Antônio Timbó Elmiro ${ }^{\mathrm{d}}$

aMestre em Análise e Modelagem de Sistemas Ambientais, Departamento de Cartografia do Instituto de Geociências da Universidade Federal de Minas Gerais. Belo Horizonte, MG, Brasil End. Eletrônico: luizacintraf@gmail.com

${ }^{b}$ Doutor em Engenharia de Transportes, professor no Departamento de Cartografia do Instituto de Geociências da Universidade Federal de Minas Gerais. Belo Horizonte, MG, Brasil End. Eletrônico: marcelo.nero@gmail.com

cDoutor em Engenharia Civil, professor no Departamento de Cartografia do Instituto de Geociências da Universidade Federal de Minas Gerais. Belo Horizonte, MG, Brasil End. Eletrônico: temba.mobile@gmail.com

${ }^{d}$ Doutor em Computação Aplicada, professor no Departamento de Cartografia do Instituto de Geociências da Universidade Federal de Minas Gerais. Belo Horizonte, MG, Brasil End. Eletrônico: timboelmiro@gmail.com

doi:10.18472/SustDeb.v11n2.2020.28145

ARTICLE- DOSSIER

\section{ABSTRACT}

The study of fire burned areas is very important, since they corroborate with control measures, prevention and monitoring of fires. Forest fires causes numerous impacts, among them, there is biodiversity lost and human health prejudice. So, it is a problem of environmental sphere as well as a social and political sphere. A way of monitoring this is using remote sensing techniques. So the propose of the present article is to use the Modis product (MCD45A1) to identify and evaluated the burned areas in metropolitan region of Belo Horizonte, among the years of 2012 to 2016, which is validated with Landsat-8/OLI sensor data. With the use of Landsat data it is possible to define the size of the 
burned area with greater precision, but requiring technical operational knowledge and specialized technical staff for both, on the other side, Modis is easier to operate, and have direct application and higher availability. It was observed that the study area has high burned area occurrences, mainly in spring and winter. The results found here could be used for future studies to decrease the forest fires incidence in the region and thus preserve the biodiversity of important biomes present in it.

Keywords: Forest fires. Landsat. Modis MCD45A1. Environmental Preservation.

\section{RESUMO}

Estudos sobre a ocorrência de queimadas são muito importantes, visto que eles corroboram medidas de controle, prevenção e monitoramento destas. Incêndios florestais causam vários impactos, entre eles perda da biodiversidade e prejuízo à saúde humana, sendo um problema tanto na esfera ambiental quanto social e política. Uma forma de monitoramento desses incêndios é a utilização de técnicas de sensoriamento remoto. Assim, a proposta do presente trabalho foi a utilização de imagens Modis (MCD45A1) para identificação e avaliação de áreas queimadas na região metropolitana de Belo Horizonte, entre os anos de 2012 e 2016, validando-o com dados do sensor Landsat-8/OLI. Com o emprego dos dados Landsat, é possivel delimitar com melhor precisão a dimensão da área queimada, mas exigindo-se conhecimento técnico operacional e corpo técnico especializado para tanto. Já o produto decorrente do Modis, é mais acessivel e de fácil utilização, sendo de aplicação direta, pois já informa os focos de incêndio. Observouse grande ocorrência de queimadas na região de estudo, principalmente na primavera e no inverno. Os resultados encontrados aqui poderão ser utilizados em estudos futuros para diminuir a incidência de queimadas na região e assim preservar a biodiversidade de biomas importantes nela presente.

Palavras-chave: Incêndios Florestais. Landsat/OLI. Modis MCD45A1. Preservação Ambiental.

\section{INTRODUCTION}

The occurrences of wildfire in vegetation represent serious concerns related to the environment, as they devastate large proportions of forests, fields and agricultural regions, causing changes in the environment. Guimarães et al. (2014) proffer the main impacts of wildfires as the following: soil warming, erosion, reduction of soil nutrients, reduction of organic matter content, soil acidity, alteration of local microclimate, reduction of water quality, animal mortality, wood weakening, cleaning of underwood, impacts on agricultural crops, interference in plant succession, reduction of microorganism activity and pasture renewal, disturbance to the surrounding population, landscape impacts and destruction of recreational areas. Ichoku and Kaufman (2005) state that wildfires cause impacts on the albedo, changes in the radiative balance of the atmosphere, changes in biogeochemical and hydrological cycles, in addition to greenhouse gases release into the atmosphere. In addition, wildfire occurrences are widely associated with the climate, vegetation conditions and especially human activities (Santos, Soares and Batista, 2006). It is also worth highlighting the approach to the subject in Louzada-Silva and Carneiro (2014) and Lima and Nasuti (2017), among others.

When a natural environment is destroyed, many plant and animal species are lost if not properly studied, which amounts to a great loss for science and humanity. Therefore, protecting and defending biodiversity becomes vital. A citable example of biodiversity loss is the Brazilian savanna known as Cerrado, where approximately 40 to $50 \%$ of the soil has been transformed into agriculture use in the last 50 years. This biome represents $23 \%$ of Brazil's land coverage being one of the most important biodiversity conservation hotspots. Another Biome heavily affected is the Atlantic Forest, which comprises $7 \%$ of the remaining original forests (GIUSTINA, SILVA and MARTINS, 2018).

The burning process in Brazil is growing and intensifies mainly in the driest periods of the year, and can be divided between natural and anthropic hotspots. The subject is also dealt with in detail in LouzadaSilva and Carneiro (2014) and Lima and Nasuti (2017). As for anthropic processes these are usually linked to the clearing of areas for agricultural and livestock expansion, in addition to being a form of management in some crops such as sugarcane (FERNANDES et al., 2016). 
Among the groups of causes of wildfires classified by FAO (Food and Agriculture Organization of the United Nations), are mostly anthropic factors including: wildfires breakout for reasons such as retaliation, revenge, land tenure disputes, urbanization and mental incapacity, among others; burning for clearing areas for agricultural purposes; smokers, due to negligence in throwing cigarette butts or lit match; forest operations and recreation (Juvanhol, 2014). It is noteworthy that it is possible to develop automated systems for monitoring and preventing disasters, as applicable to the landslide area, as cited by Saito, Lima and Dias (2019). However, it is also worth mentioning, researches focused on the area of fire prevention, presented in Ribeiro et al (2008), Ribeiro (2009), Prudente (2010), Zhang et al (2011), Oliveira and Nero (2012, 2013), Oliveira (2013), Oliveira et al (2017), Fernandes (2019), Fernandes et al (2018a, 2018b, 2019).

In addition to the impacts of biodiversity loss, wildfires pose a major risk to human health, as they emit tiny particulate matter that damages the respiratory system. These particles are deposited in the terminal bronchi and in the alveoli, aggravating respiratory problems. Thus, municipalities located near the burned areas have increasingly recorded public health problems. Thus, it is estimated that in the next 20 years air pollution will be responsible for about 156,000 deaths, 4 million cases of asthma and 300,000 children health related problems consulting (CASTRO et al., 2016)

Considering all that has been discussed here, it can be said that the problem of burning involves both social issues, such as public health issues, and environmental issues related to biodiversity losses. Therefore, in taking measures to prevent and controlling this phenomenon, it is necessary first to study and understand it. Hereby, awareness of the highest place of occurrence, frequency of events, times of the year, among others, are of vital importance. From this data it becomes possible to identify the causes and the best ways to control and prevent wildfires. Thus, it is important to have a quick and efficient way of detecting forest fires, to improve the control, and monitor burned areas, obtain cost reductions in combat operations, allow damage mitigation and estimate the impacts caused in the region. Detection can be carried out in different ways, such as through: surveillance posts, observation towers, aerial patrolling and monitoring through satellite images (BATISTA, 2013).

Remote sensing techniques stands out as a good solution when the objective is to map wildfires in areas with difficult access, such as conservation units and rural areas. Since there are no monitoring in these areas and the registration is done only through denouncements. Remote sensing consists in obtaining information from an object or target, without physical contact with it, and the information obtained using electromagnetic radiation reflected and/or emitted by the targets (ROSA, 2011). In addition, remote sensing allows the identification of thematic classes on the earth's surface, as well as the area of occurrence, exploring the classes of land use. Additionally, due to its temporal domain, it also identifies changes in objects on the surface, very important mainly for planning and environment monitoring. With the integration of its spectral and spatial characteristics it is possible to extract information regarding the product from a single date or a few dates. As an example, we have the Normalized Difference Vegetation Index (NDVI), where, through the use of reflectance in the red band and near infrared band ranges, information is provided on the amount of photosynthetically active green biomass of vegetation (PEREIRA FILHO, 2014). Thus, remote sensing techniques can be used for wildfire occurrence awareness, as well as in the quantification of the area and biomass affected by the wildfire (FRANÇA and FERREIRA, 2005).

In terms of environment, it is noteworthy mentioning several works that apply remote sensing, such as: 1) that performed by Barbalho et al (2019) with the use of 'Rapideye images' together with geoprocessing techniques; 2 ) the use of ArcGIS (Geographic Information Systems processing program, GIS) with the use of Google Earth images, as described in Viera et al (2018); 3) research with the application of GIS and temporal analysis of environmental devastation studies, reported in Guistina et al (2018).

Three sources of radiation are involved in the detection of wildfires by remote sensing: the emission of the fire itself, as combustion substances, the emission and reflection of the hotspots area, and the reflection of other sources, such as exposed soil. The use of surface changes between vegetation and 
exposed soil is one of the most used ways to detect burned areas, as an example, we have the use of satellite images from the LANDSAT and SPOT systems, are immensely potential for this purpose, owing to their minute spatial resolution in relation to other sensors (França and Ferreira, 2005). Another form of detection is that used by Resende et al. (2017), who have used the Linear Spectral Mixing Model (LSMM) (Shimabukuro and Smith, 1991) from Moderate Resolution Imaging Spectroradiometer (MODIS) sensor images to identify the burned area in the Northeast portion of the Cerrado within the years 2012 to 2015.

Another related study is that of Fornazari et al (2015) where LANDSAT-5/TM sensor images was used to map the scars of the burned parts in the Serra do Cipó National Park (MG), in its study it was concluded that this method showed limitations when analyzing the permanence of the scars associated with the variables' "size" and "precipitation". The presence of clouds promoted the obscuration of several scenes acquired by the LANDSAT-5/TM sensor due to its low temporal resolution, so that possible scars present in this clouded region were left unmapped. Despite the difficulty of the method, it was noted that there is a considerable increase in the incidence of wildfire in the region in the months of June, September and October.

Rodrigues et al (2018) used an automatic estimate of the burned area in the Serrana Region of Rio de Janeiro in October 2014, through information from the operational land imager (OLI) sensor on board LANDSAT- 8 satellite. Due to the low time frequency of the LANDSAT- 8 images ( 16 days) and the frequent presence of high cloudiness in the region, it was only possible to map the burned areas two months after the event. The quantitative results indicate a total of approximately 4000 ha of burnt area in the Conservation Unit. The importance of using products with greater temporal frequency is noted, since in this study it was possible to detect the phenomenon only two months after the event, there may be loss of information.

The MODIS sensor, aboard the TERRA and AQUA orbital platforms, is configured to provide data on the dynamics of the Earth's biosphere, allowing the generation of images with spatial resolution between 250 and 1000 meters, in addition to presenting a frequency of revisit between 1 and 2 days to the equator (Piromal et al., 2008). The MCD45A1 is a product obtained from images of both MODIS sensors with a monthly frequency and spatial resolution of $500 \mathrm{~m}$, containing wildfire identified by pixel and presenting quality information of the data. The algorithm used to generate this product is based on changes in coal and ash deposits, removal and alteration of vegetation structure. Thus, the date of the burning is detected by locating the occurrence of rapid changes in the data of the daily surface reflectance time series, and a comparison is made between the reflectance data from the previous days, resulting in a statistical measure to determine whether the difference between predicted and observed reflectance denotes a significant change (ROY et al., 2005).

The LANDSAT series of satellites, which presents spatial resolution between 15 and $30 \mathrm{~m}$ (depending on the spectral band), has been consolidated as one of the main tools for analysis and evaluation of environmental impacts, land use and land cover, estimation of biophysical parameters, georeferencing, as well as agricultural and environmental planning (ALVES et al., 2017). Examples of recent related work are in Bittencourt and Guasselli (2017), Sotille et al. (2016), Andrade and Lourenço (2016), and Paula et al. (2016).

Data from LANDSAT satellites are widely used in the validation of methodologies for wildfire detection as a result of outstanding outcome derived from their applications, as portrayed by the citable authors who applied this validation. These authors include Jesus et al. (2011), Matos and Leal (2014), Piromal et al. (2008) and Tomzhinski et al (2011). In the same vein, Araújo and Ferreira Junior (2011) validated the MCD45A1 product with data from LANDSAT-5, in the Cerrado region, and obtained $100 \%$ of the polygons found by MODIS were positively labeled as burned, due to the good accuracy of the algorithm. Cardozo et al. (2012) did the same validation for a region of the Amazon Rainforest and obtained more than $90 \%$ omission of burned areas. The advantages of using LANDSAT data is related to its better spatial resolution among the satellite data with free access. 
In this context, the present work aimed at evaluating the occurrence of fires in the metropolitan region of Belo Horizonte, during the dry season, from the year 2012 through 2016. For this purpose, MCD45A1 product data from the MODIS sensor were used. In addition, the obtained results in relation to the estimated burned area were compared with the same data generated from orbital images of the LANDSAT-8/OLI sensor.

\section{MATERIALS AND METHODS}

The investigation of the occurrence of fires consisted of two main steps. The first dealt with the acquisition of MCD45A1 product data from the year 2012 to 2016, treatment of the data and the estimation of the extent of burned area. The second step was comparing the results of MCD45A1 with images from the LANDSAT-8/OLI system, as it has better spatial resolution and better spectral response to the occurrence of wildfires and it is widely used in studies for this purpose. The comparison was made only as for the periods of higher wildfire occurrences in this study.

\subsection{FIELD OF STUDY}

The Metropolitan Region of Belo Horizonte (Região Metropolitana de Belo Horizonte-RMBH), lies in the State of Minas Gerais and its main accesses are by highways BR-040, BR-381 (Fernão Dias Highway), BR-356 and BR-262, as shown in Figure 1. The region is composed of 34 municipalities, with a territorial extension of $9460 \mathrm{Km} 2$, being the 3rd largest metropolitan region in Brazil and the 7th largest in Latin America. It has a population of approximately 5 million inhabitants and a GDP of 56.8 million, corresponding to $40 \%$ of the state's GDP (Agencia RMBH, 2016). The region covers three hydrographic basins: Rio das Velhas Basin, Rio Paraopeba Basin and Rio Pará Basin, all sub-basins of the São Francisco River (RMBH AGENCY, 2016).

The RMBH is present between two biomes: Atlantic Forest and the Cerrado. The former is predominantly characterized by the ombrophilous and seasonal forest physiognomies (semideciduous and deciduous). While the Cerrado is predominantly characterized by the savanna physiognomies (OLIVEIRA FILHO, 2006), apart from forestry and pasture. The Atlantic Forest represents the second largest tropical rainforest in the Americas, being one of the 25 world hotspots of biodiversity. Despite having been largely destroyed, it is still home to over 8,000 endemic species of vascular plants, amphibians, reptiles, birds and mammals (MYERS et al., 2000). The Cerrado is one of the main savanna formations in the tropics, being the second largest biome in South America, occupying $22 \%$ of the Brazilian territory, and at the same time, being the biome that concentrates the largest agricultural production in the country (MARQUES et al., 2017).

The climate classification of the region covers four climate zones defined by Nimer (1979). The zones of the greatest expression are: Tropical Central Brazil mild mesothermal semi-humid and Tropical Central Brazil sub-humid climate. The Tropical Central Brazil semi-humid climate stands out for an annual rainfall regime characterized by a pronounced concentration of tropical instabilities in summer, while the winter is strongly marked by drought (for around 4 to 5 months).

The low humidity makes the region prone to forest fires. According to data provided by FEAM (2017) there was the burning of over 2783 ha between 2012 and 2016in the state conservation units. 


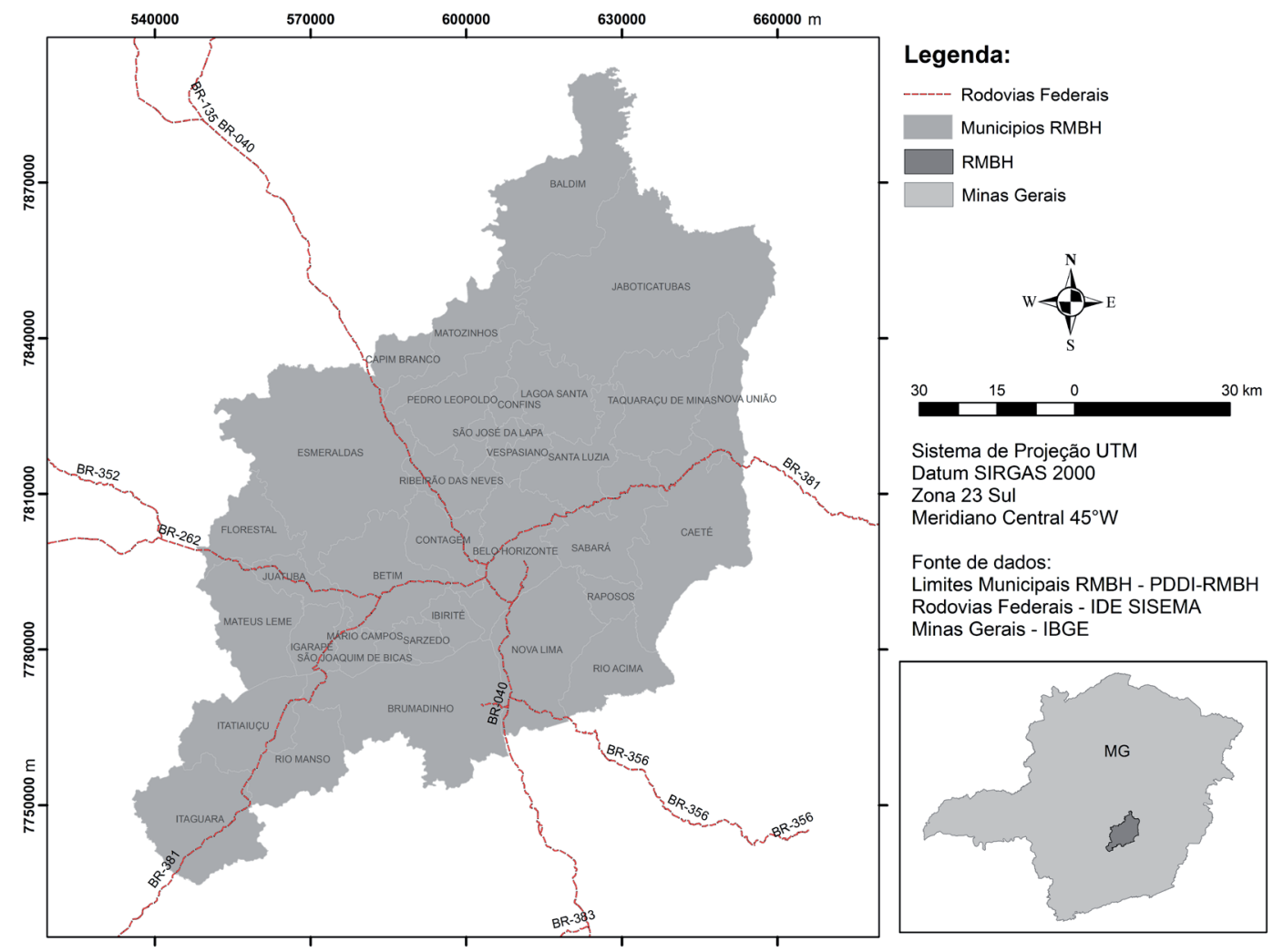

Figure 1 | Location of the area and study.

Source: Authors, based on PDDI (2014), ESRI (2015), IBGE (2017).

\subsection{ASSESSMENT OF BURNED AREAS BY MODIS SENSOR}

The acquisition of the product MCD45A1 was made in NASA (2017), from https://ladsweb.modaps. eosdis.nasa.gov, where the images were acquired in geotiff format. In this image acquisition, the geographical limits of RMBH which is inserted in tiles H13V11, H13V10, H14V11 were considered and the area of interest where isolated. The images obtained considered the situation from January to December, from 2012 to 2016, totaling 60 images.

The product MCD45A1 provides eight by-products, of which only two were used in this analysis, the by-product ba_qa (reliability index and pixel labeled as burned) and the by-product burndate (index that indicates if the area is burned). In order to obtain the pixels with high reliability index, the two bands were crossed. The value of the pixels of the by-product $b a \_q a$, varies from 0 to 5 , and only pixels with value 1 , which represent the highest reliability, were selected. The values of the pixels of the byproduct burndate represent the day of the wild fire occurrence, in the format of the Julian calendar, allowing the awareness of the exact days in which more wildfires occurred.

The burned area for each year was calculated, taking the product's spatial resolution, which is $500 \mathrm{~m}$, into account. All data were treated using procedures developed in Interactive Data Language (IDL), an interactive computer programming environment integrated with ENVI software (version 5.2), a platform for remote sensing data treatment and digital image processing.

\subsection{ASSESSMENT OF BURNED AREAS WITH LANDSAT DATA}

LANDSAT-8/OLI images were acquired from the Earth Explorer website(USGS, 2017), through the link https://earthexplorer.usgs.gov, referring to the orbit/point 218/74 that covers part of the study region. The images were chosen considering the smallest cloud coverage possible. Thus, 4 images were 
acquired (September and November 2014, August and September 2016). As it was not possible to find images with total absence of clouds, we used clippings that obeyed this condition, besides data with LANDSAT-8/OLI quality to verify their presence.

The raw digital values of the images were converted into apparent reflectance for image correction using the LANDSAT-8/OLI radiometric image correction method provided by USGS (United States Geological Survey), which is based on the relationships proposed by Markham and Barker (1987).

For the recognition of wildfire scars, the NDVI images were calculated (Equation 1) by an operation between the near infrared (IR) and red (R) bands. Assuming that the greater the amount of vegetation, the greater the reflection in the infrared band and smaller in the red band, increasing the ratio value and enhancing the vegetation (MELO, SALES and OLIVEIRA, 2011).

$$
N D V I=(N I R-R) /(N I R+R)(1)
$$

From NDVI images, from the period before the burn (T1) and the period after (T2), the differences of these images (T1-T2) are calculated to help verify the burned part scars.

\section{RESULTS}

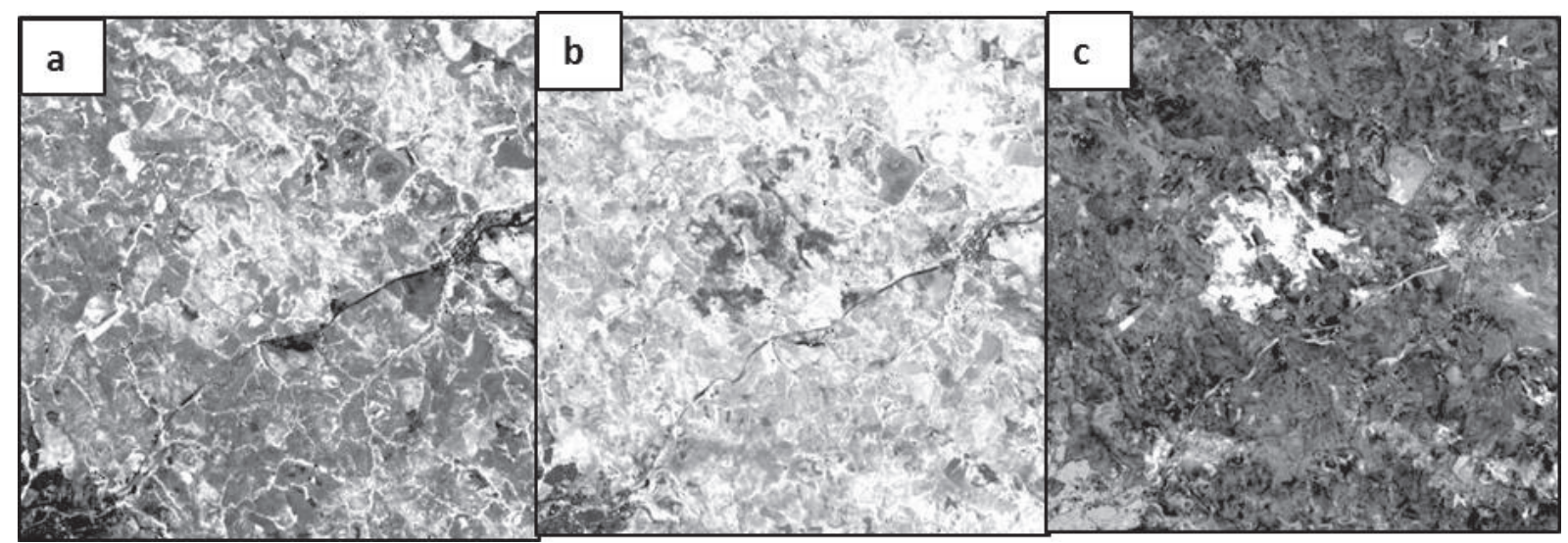

Figure 2 | NDVI T1 (August 2014) (a), NDVI T2 (September 2014) (b) and T1-T2 (c).

Source : Authors, based Landsat/OLI 8 images.

As shown in Figure 2, the image difference allows the identification of pixels where there was no difference with values close to 0 , places with vegetation removal, values close to 1 and vegetation growth, values close to -1 (CARVALHO; SCOLFORO,2008). It is possible to identify and demarcate the scars through regions of interest (ROI). Using the ROI (Region of Interest) tool, available in the ENVI software, a number of representative pixels (seed pixels) are selected from growth methods of regions based on the similarity of seed pixels with their neighbors, delineating the region efficiently, producing an optimized and accurate outline of the scar.

The pixel quantities of burned areas by LANDSAT-8/OLI and MODIS were compared and whether the areas were corresponding. It was noted that all burned polygons found based on the MODIS sensor data were also identified in the LANDSAT-8/OLI images, an example is shown in Figure 3. Nevertheless, when pixel matching was checked, it was observed that MODIS data was able to verify $72 \%$ of the wildfire pixels in 2014 and $60 \%$ of the fire pixels for 2016. 


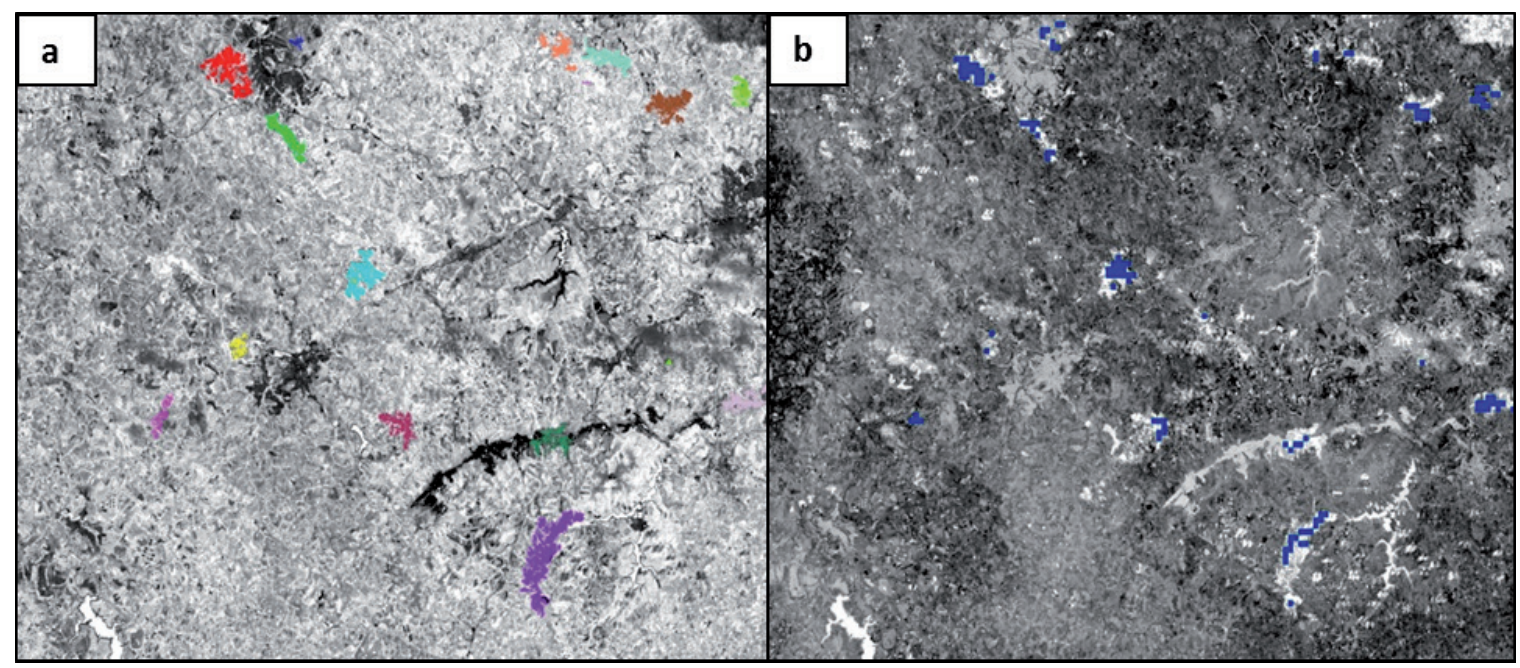

Figure 3 | Comparison of burned polygons detected by LANDSAT-8/OLI images (colors only to differentiate each burn scar) (a) and MODIS sensor (b)

Source: Authors, based Landsat/OLI 8 images.

\subsection{ANALYSIS OF THE WILDFIRE OCCURRENCE}

With the burned area data obtained by the product MCD45A1 some analyses were made. Therefore, it was possible to notice that the seasons of the year in which wildfire occur mostly are winter and spring, though there were few points of wildfires in autumn, whereas in summer none was detected (figure 4).

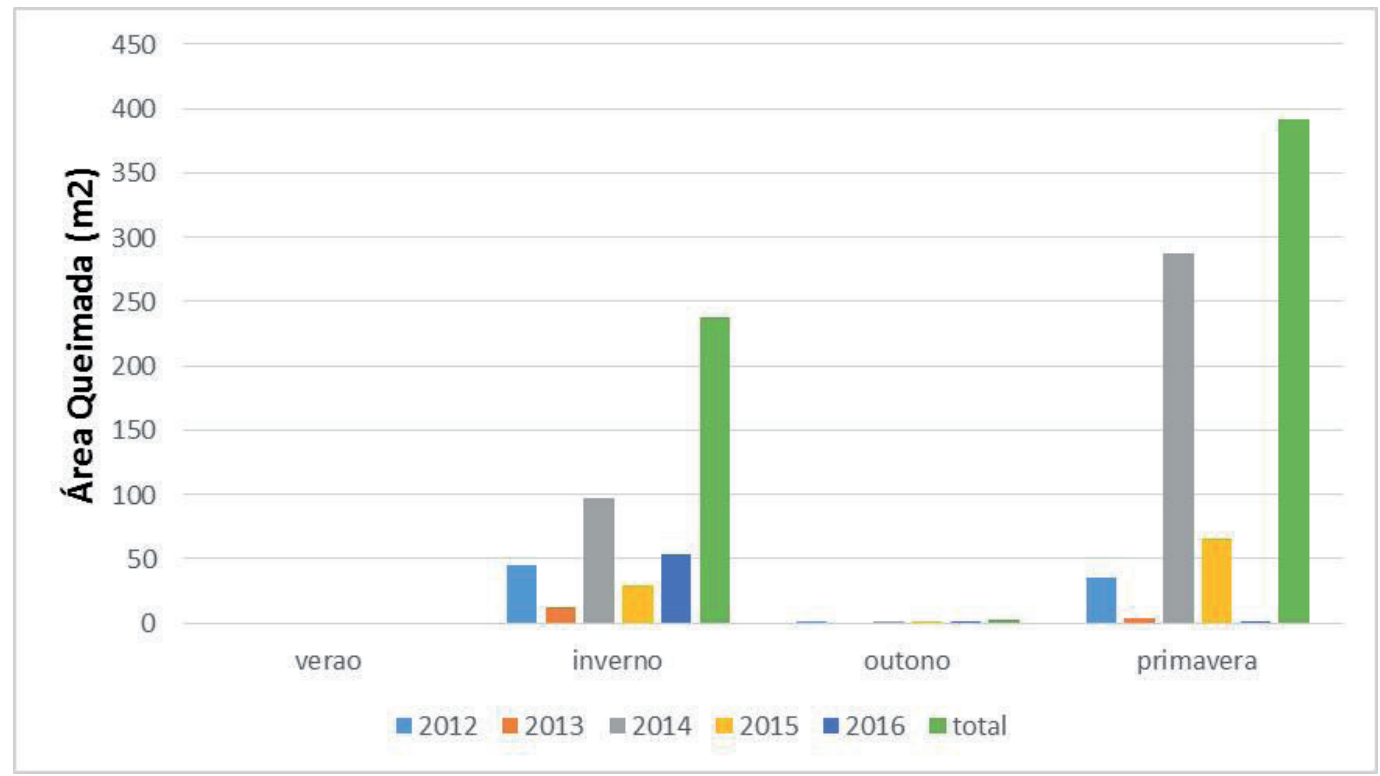

Figure 4 | Burned area by seasons.

Source: Authors.

Comparing the annual total (figure 5), it can be seen that the year 2014 gained prominence as the year with the highest incidence of wildfire, with $350 \mathrm{~km} 2$ of affected area. It was followed by the year 2015, with $81 \mathrm{~km} 2$ of affected area. 


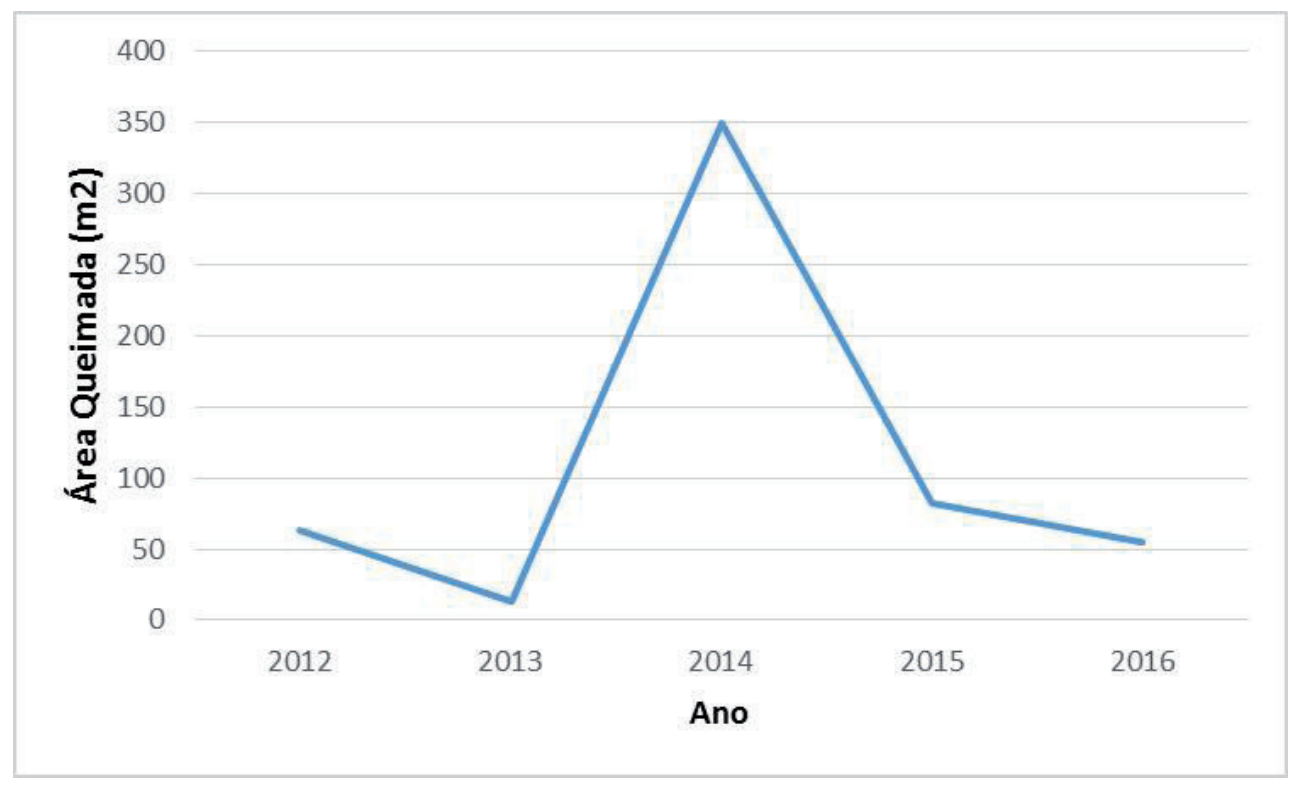

Figure 5 | Burned area by year

Source: Authors.

Between the months (figure 6) those with the highest concentration of wildfire are August, September and October. It should also be noted that the month of October presented an expressive value due to the year 2014, where wildfires occurrences were registered at a considerably high rate, reaching an area of approximately $183 \mathrm{~km} 2$, escalating to the record of the month with highest value of burned area throughout the years studied.

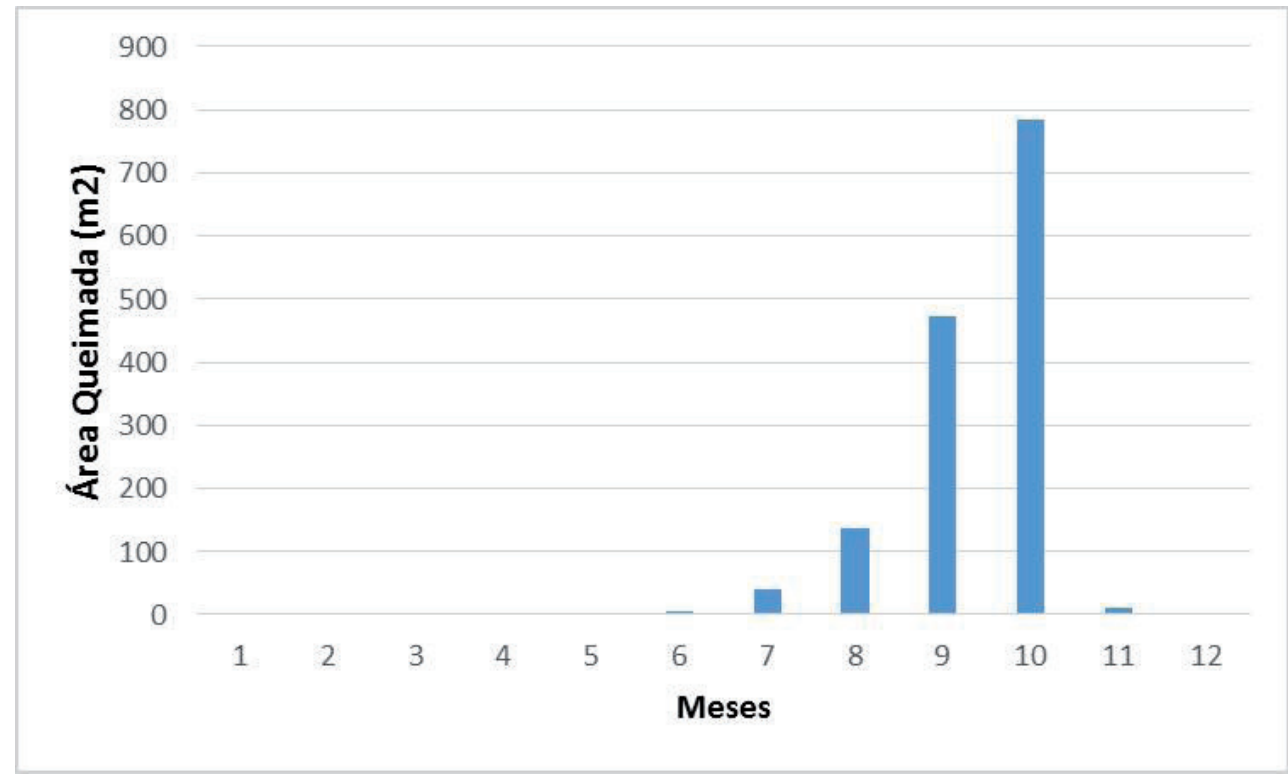

Figure 6 | Burned area by months

Source: Authors.

From the land use and land cover mapping data made available by MapBiomas (2017), it was possible to make an analysis of the types of land cover most affected by fire. The data was cross-checked with the burned areas data from MODIS (figure 7), and the most affected areas for the years of study were: $33 \%$ of burned areas in Forest Formation areas, $26 \%$ in pasture areas and $12 \%$ in mosaic areas of agriculture and pasture. 


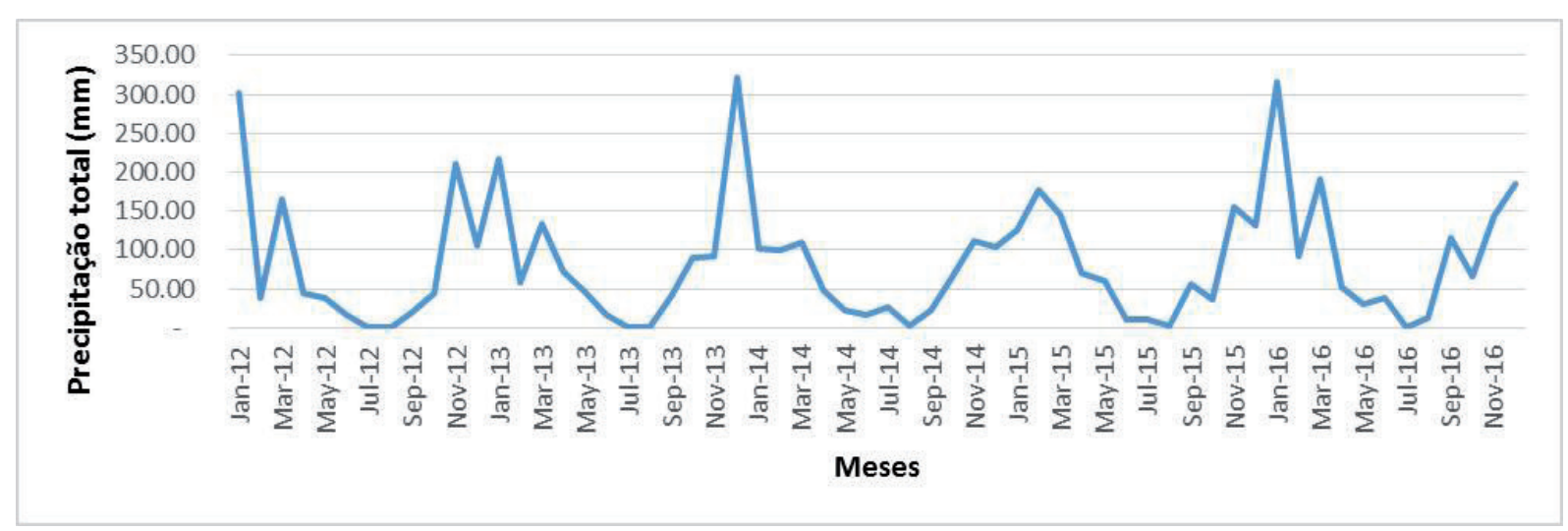

Figure 7 | Types of land cover where pixels from wildfires were detected during the years of study. Source: Authors.

\section{DISCUSSIONS}

In figure 8 , it is possible to better understand the results, since the variation in total precipitation during the studied years is presented. It is possible to understand the relationship between precipitation and burned areas, in the year 2014 a large decrease in precipitation was identified, since most months had a total precipitation of less than $50 \mathrm{~mm}$. The year 2015 was the second year with the highest rate of wildfires, which may still be due to the low precipitation the state was suffering then. In 2016, coincidently, there was the increase in the precipitation and decrease in the burned area.

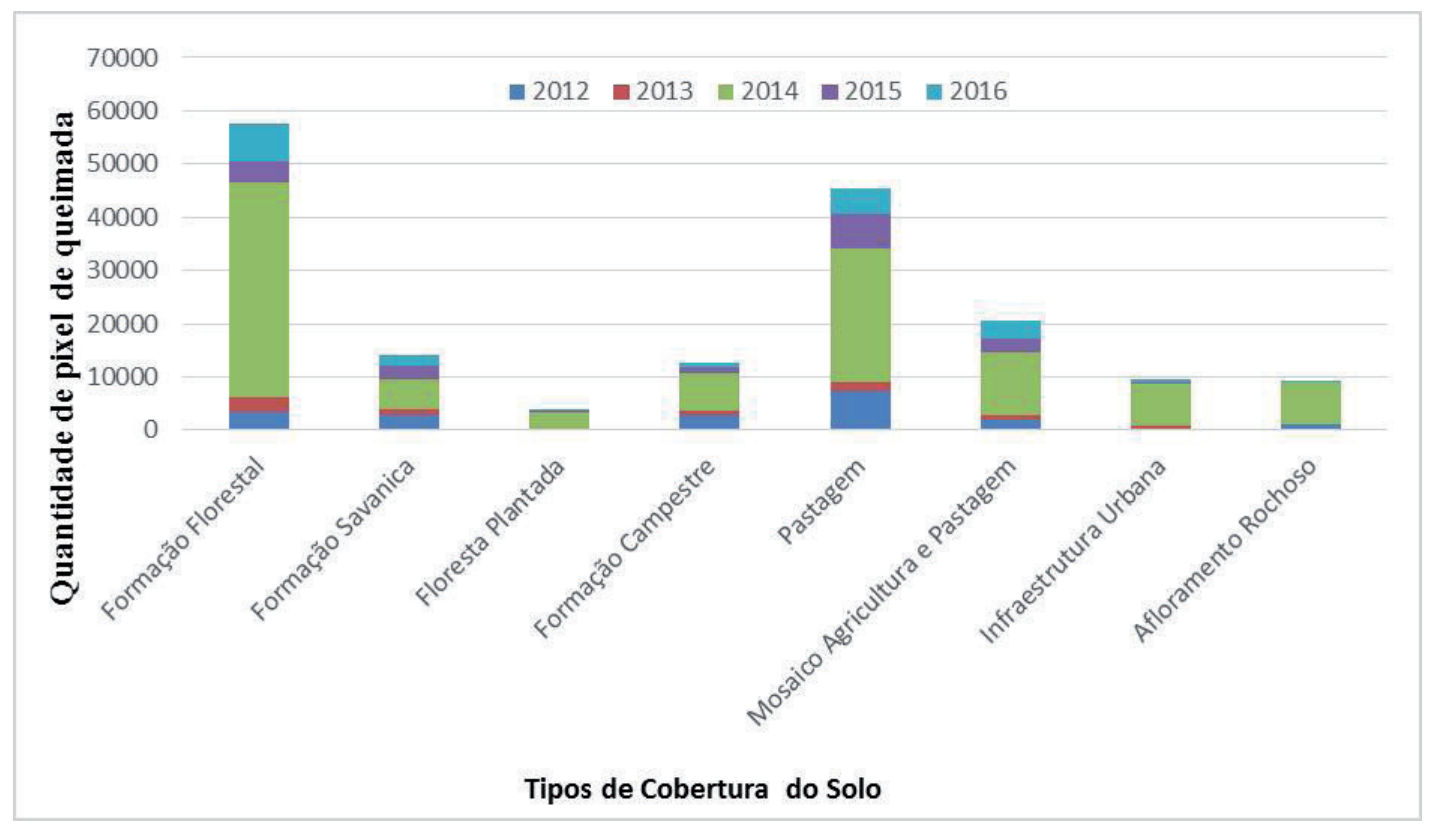

Figure 8 | RMBH accumulated precipitation.

Source: (ANA, 2018).

It is possible to observe the coherence of the data in figure 4, since the seasons with lower rainfall values are during winter and spring, which are also the seasons with the highest rate of wildfires. It can be observed that the highest occurrence was registered in spring. This fact can be attributed to the combination of low precipitation together with higher temperatures.

The above cited study of Fornazari (2015) also shows a considerable increase in the wildfire incidence in the region in June, September and October. This is in line with what was detected in this study, remembering that part of Serra do Cipó lies in the RMBH. 
The most affected areas by wildfires are forest areas, which mostly comprise areas of Atlantic Forest, showing the importance of verifying the occurrence of wildfires in the region. This is because it is a very rich region in biodiversity, which ends up being a loss with the occurrence of forest fires.

Other highly affected areas are areas used for agriculture and pasture. This can be related to burning for cleaning areas, which can also be associated with the occurrence of fire outbreaks in other regions.

Since fire needs an ignition to start and it is often associated with human causes. The fact that it has a higher incidence in drier season does not mean that the climate is the only "culprit". What happens is that with the decrease in precipitation and the consequent drop in air humidity, there is a drop in the humidity of the combustible material (wood), which makes it more prone to ignition. Plus, the drop in soil humidity, which is more prone to spread fire, burning larger areas, which are easier to identify by satellites. This highlights the importance of greater surveillance in these regions, especially in times of lower precipitation.

As for the way of satellite detection of wildfire, it was found that using MODIS sensor data instead of LANDSAT-8/OLI data to detect the sites with burnt area, does not affect the result, as the polygons have overlapped.

The use of LANDSAT images, on the other hand, due to its better spatial resolution, allows to better identify the dimension and delimitation of burnt areas. It should be noted, however, that only the most reliable pixels of the MODIS sensor were used (value 1 of ba_qa index). If other arrangements were used, considering lower reliability indexes, it would be possible to achieve a better matching of the areas.

The handling of LANDSAT-8/OLI data requires more time and processing and depends on the user for the identification of the areas as presented in "figure $2 c^{\prime}$ " and the selection of the seed pixel for area growth. Whereas, the MODIS sensor data was practically ready for direct use.

Another advantage of the MODIS sensor in relation to LANDSAT-8/OLI is its temporal resolution, the former having a resolution of 1 and 2 days, while the latter has a frequency of 16 days and still has the aggravating factor of having many images with the presence of clouds, which makes detection difficult, as evidenced in Rodrigues et al (2018).

\section{CONCLUSIONS AND FUTURE PROSPECTS}

The availability of detailed and up-to-date information on the spatial (location and extent) and temporal distributions of burned areas is currently crucial, not only for the better management of natural resources, but also for atmospheric chemistry and climate change studies.

The large occurrence of fires associated with both meteorological and anthropic factors is a growing concern, since it causes impacts on the society and the environment. Therefore, it is very important to develop research and scientific studies that cooperate with the monitoring of fire outbreaks and risks. It was observed that the greatest amount of fires occurred mainly in the months of September and October, where larger quantities of burned areas were found. At that time of the year the humidity of the air becomes low, while the temperature gets higher, which decreases the humidity in the fuel material and in the soil, which cooperates with the spread of fires. It was noted that the burned areas are strongly linked to the occurrence of precipitation, and in the times of occurrence of less precipitation the largest amounts of burned areas were found.

Remote sensing techniques are important in the burn detection process, as remote monitoring is possible, having a lot of quality data available. The option of using LANDSAT system data or MODIS sensor data for wildfire studies depends on the purpose of the application. 
With the use of the first sensor it is possible to delimit the size of the burned area more precisely, but the use of this method requires more processing work, in addition to external references, as it depends on radiometric transformations, vegetation index calculations and visual interpretation of image data. In addition, the difficulty of finding images with no clouds, depending on the time of interest was encountered. On the other hand, the product resulting from MODIS does not delimit the outline of the burnt area with the same accuracy, but it detects the places where the wildfire occurred, being of direct application, high availability and easy to use. This fact greatly favors public management, where often there may not be such a skilled technical staff, either due to lack of resources or due to unawareness of the managers themselves.

Therefore, the MCD45A product of the MODIS sensor is a readily available resource, which adds speed and simplicity to wildfire studies, particularly in the verification of higher risk areas and their regular monitoring, presenting additional advantages over other existing methods. However, it should be noted that the present study does not exhaust the subject matter, which is indeed very broad and deserves further investigation.

Another possibility is the use of the Normalized Burn Ratio (NBR) instead of the NDVI in other studies. It is suggested in other studies to divide the study into two periods of the year: early (from October 16 to August 15) and late (from August 16 to October 15). It should be emphasized that these periods are those adopted by the management bodies in decision making regarding the management of fire occurrences applied to protected areas. Other possibilities would also include carrying out other analyses in order to prevent and fight wildfires in the study area, such as: maximum and average extension of wildfires (affected area) each year; frequency of wildfires (number of times each pixel burned in the analysis period), seeking to identify the critical areas and highest risk for protected areas correlating with the type of soil, for example; differences in fire occurrences inside and outside the protection areas; identification of the protected areas most vulnerable to fire outbreaks (quantified by the frequency of wildfires and higher extension).

Additionally, it is important to validate these with field data to verify that the pixels actually correspond to burned areas. The availability of wildfire data is a difficulty, these were requested from the Fire Department and could not be made available for safety reasons. An attempt was made to request these data from the agency responsible for forests protection in Minas Gerais, Instituto Estadual de Florestas de Minas Gerais (IEF), which also did not have this type of data observed and computed. It is therefore important to verify ways of monitoring and recording these fires in order to improve detection techniques.

The results obtained in this work can effectively contribute to the prevention of socio-environmental impacts in the study region and can serve as a model for application in other metropolitan regions aiming at sustainability.

\section{REFERENCES}

AGÊNCIA NACIONAL DE ÁGUAS. Séries Históricas de Estações. Disponível em: <http://www.snirh.gov.br/ hidroweb/publico/medicoes_historicas_abas.jsf>. Acesso em: 1 jun. 2018.

AGÊNCIA RMBH. RMBH e Colar Metropolitano, 2016. Disponível em: <http://www.agenciarmbh.mg.gov.br/ rmbh-e-colar-metropolitano/>. Acesso em: 20 out. 2016.

ALVES, L. E. R. et al. Balanço de radiação através do satélite Landsat-8 na Bacia do Rio Pajeú. Geography Department University of São Paulo, v. 33, p. 117, 2017.

ANDRADE, F. M.; LOURENÇO, R. W. Uso do Solo e Cobertura Vegetal na Bacia Hidrográfica do Rio Una - Ibiúna/SP. Geography Department University of São Paulo, v. 32, n. 0, p. 48, 2016. 
BARBALHO, M. G. DA S. et al. Permanent preservation, coverage area and use of the land in the hydrographic basin of the Almas River, microregion de Ceres, Goiás, Brazil. Sustentabilidade em Debate, v. 10, n. 3, p. 147-178. 2019. Disponível em: <https://doi.org/10.18472/SustDeb.v10n3.2019.24751>. Acesso em: 04 jun. 2020.

BATISTA, A. C. Detecção de Incêndios Florestais por Satélites. Journal of Chemical Information and Modeling, v. 53, n. 9, p. 1689-1699, 2013.

BITTENCOURT, D. Z.; GUASSELLI, L. A. Dinâmica de Inundação do Banhado a partir do índice NDPI, Reserva Biológica de São Donato - RS. Geography Department University of São Paulo, v. 33, p. 85, 2017.

CASTRO, F. R. DE et al. Impactos das Queimadas sobre a Saúde da População Humana na Amazônia Maranhense. Revista de Pesquisa em Saúde, v. 7, n. 3, p. 141-146, 2016.

FERNANDES, A. C. G. et al. Utilização de intervalos de índices de vegetação e temperatura da superfície para detecção de queimadas. Caderno de Ciências Agrárias, v. 8, n. 2, p. 30-40, 2016.

FERNANDES, L. C. Modelagem de risco de incêndios florestais utilizando redes neurais artificiais aplicada às regiões metropolitanas. Dissertação (Mestrado) - Universidade Federal de Minas Gerais, Belo Horizonte, 2019, 146p.

FERNANDES, L. C. et al. Fire Risk Modeling Using Artificial Neural Networks. EngOpt 2018. Proceedings of the 6th International Conference on Engineering Optimization. Springer International Publishing, 2019, p. 938-948.

FERNANDES, L. C. et al. Modelagem de Risco de Incêndios Florestais: uma visão geral. Sodebrás, v. 13, p. 79-84, 2018a.

FERNANDES, L. C. et al. Modelagem de risco de incêndio utilizando Redes Neurais Artificiais. In: XXVI JORNADAS DE JÓVENES INVESTIGADORES DE LA AUGM, 2018b, Mendoza-Argentina. XXVI JORNADAS DE JÓVENES INVESTIGADORES DE LA AUGM. Mendoza-Argentina: AUGM, 2018.

FRANÇA, D. DE A.; FERREIRA, N. J. Considerações sobre o uso de satélites na detecção e avaliação de queimadas. In: XII SIMPÓSIO BRASILEIRO DE SENSORIAMENTO REMOTO. Anais... Goiânia, GO: Inpe, 2005.

FUNDAÇÃO ESTADUAL DO MEIO AMBIENTE. Dados conseguidos junto ao órgão responsável, 2017.

GIUSTINA, C. C. DELLA; SILVA, S. D. E.; MARTINS, E. D. S. Geographic reconstruction of a Central-West Brazilian landscape devastated during the first half of the 20th century: Mato Grosso de Goiás. Sustentabilidade em Debate, v. 9, n. 3, p. 44-63, 2018.

GUIMARÃES, P. P. et al. Análise dos impactos ambientais de um incêndio florestal. Agrarian Academy, v. 1, n. 1, p. 38, 2014.

ICHOKU, C.; KAUFMAN, Y. J. A method to derive smoke emission rates from Modis fire radiative energy measurements. IEEE Transactions on Geoscience and Remote Sensing, v. 43, n. 11, p. 2636-2649, nov. 2005.

JESUS, S. C.; SETZER, A. W.; MORELLI, F. Validação de focos de queimadas no Cerrado em imagens TM/Landsat-5. In: XV SIMPÓSIO BRASILEIRO DE SENSORIAMENTO REMOTO - SBSR. Anais... Curitiba, PR: Inpe, 2011

JUVANHOL, R. S. Modelagem da vulnerabilidade à ocorrência e propagação de incêndios florestais. [s.l.] Universidade Federal do Espírito Santo, 2014.

LIMA, V. DA S., NASUTI, S. Universo Quebradeiras. Sustentabilidade em Debate, v. 8, n. 2, p. 147-169. 2017. Disponível em: <https://doi.org/10.18472/SustDeb.v8n2.2017.26924>. Acesso em: 04 jun. 2020.

MAPBIOMAS. Projeto MapBiomas - Coleção [3] da Série Anual de Mapas de Cobertura e Uso de Solo do Brasil. Disponível em: <http://mapbiomas.org>. Acesso em: 1 jun. 2018.

MARKHAM, B. L.; BARKER, J. L. Thematic Mapper bandpass solar exoatmospheric irradiances. In: International Journal of Remote Sensing. [s.I: s.n.]. v. 8, p. 517-523.

MARQUES, C. B. et al. Análise de correspondência entre mapas de vegetação florestal do bioma Cerrado. XVIII SIMPÓSIO BRASILEIRO DE SENSORIAMENTO REMOTO - SBSR. Anais... 2017. Disponível em: <http://urlib. net/8JMKD3MGP6W34M/3PSM4HJ>. Acesso em: 1 jun. 2018. 
MATOS, N. M. DE; LEAL, F. A. Mapeamento temporal e validação de áreas queimadas por meio do produto Modis MCD45A1 para o bioma Pantanal. 5o SIMPÓSIO DE GEOTECNOLOGIAS NO PANTANAL. Anais... Campo Grande - MS, 2014

MELO, E. T.; SALES, M. C. L.; OLIVEIRA, J. G. B. DE. Aplicação do índice de vegetação por diferença normalizada (NDVI) para análise da degradação ambiental da microbacia hidrográfica do Riacho dos Cavalos, Crateús-CE. Raega - O Espaço Geográfico em Análise, v. 23, n. 23, p. 520-533, 2011.

MYERS, N. et al. Biodiversity hotspots for conservation priorities. Nature, v. 403, p. 853, 2000.

NASA. Dados Modis. Disponível em: <https://ladsweb.modaps.eosdis.nasa.gov/>. Acesso em: 1 jun. 2018.

NIMER, E. Climatologia do Brasil. Rio de Janeiro, 1979.

OLIVEIRA, A. L. S. Modelagem espacial de predição de riscos de incêndios com lógica fuzzy, comparação e validação. Dissertação (Mestrado) - Universidade Federal de Pernambuco, Recife, 2013, 161p.

OLIVEIRA, A. L. S. et al. Comparação e validação da modelagem espacial de riscos de incêndios considerando diferentes métodos de predição. Boletim de Ciências Geodésicas, v. 23, p. 556-577, 2017.

OlIVEIRA, A. L. S.; NERO, M. A. Application of Fuzzy Logic in Prediction of Fire in João Pessoa City - Brazil. Communications in Computer and Information Science (Print), v. 399, p. 323-334, 2013.

Mapa de análise de risco de incêndios florestais: estudo de caso no município de João Pessoa - Paraíba, Brasil. In: 9 SINAGEO - SIMPÓSIO NACIONAL DE GEOMORFOLOGIA, 2012, Rio de Janeiro - RJ. Anais... Rio de Janeiro - RJ, 2012.

OLIVEIRA FILHO, A. T. DE. Definição e delimitação de domínios e subdomínios das paisagens naturais do estado de Minas Gerais. In: SCOLFORO, J. R.; CARVALHO, L. M. T. DE (Ed.). Mapeamento e inventário da flora nativa e dos reflorestamentos de Minas Gerais. 2. ed. Lavras: UFLA, 2006. p. 21-35.

PAULA, M. R. DE; BENEDETTI, A. C. P.; PEREIRA FILHO, W. Influência do Uso e Cobertura da Terra aliada à Precipitação Pluviométrica na Qualidade da Água da Bacia Hidrográfica do Rio Ingaí - RS/Brasil. Geography Department University of São Paulo, v. 32, p. 143, 2016.

PEREIRA FILHO, W. Cartografia e sensoriamento remoto na avaliação de dados com abordagem espaço e tempo. Geography Department University of São Paulo, v. Especial C, n. spe, p. 426, 2014.

PINTO FILHO, J. L. DE O.; PETTA, R. A.; SOUZA, R. F. Caracterização Socioeconômica e Ambiental da População do Campo Petrolífero Canto do Amaro, RN, Brasil. Sustentabilidade em Debate, v. 7, n. 2, 2016. Disponível em: <l:https://doi.org/10.18472/SustDeb.v7n2.2016.17489>. Acesso em: 04 jun. 2020.

PIROMAL, R. A. S. et al. Utilização de dados Modis para a detecção de queimadas na Amazônia. Acta Amazonica, v. 38, n. 1, p. 77-84, 2008.

RESENDE, F. C.; CARDOZO, F. D. S.; PEREIRA, G. Análise Ambiental da Ocorrência das Queimadas na Porção Nordeste do Cerrado. Geography Department University of São Paulo, v. 34, p. 31, 2017.

ROSA, R. Geotecnologias na geografia aplicada. Revista do Departamento de Geografia, v. 16, p. 81-90, 2011.

ROY, D. P. et al. Prototyping a global algorithm for systematic fire-affected area mapping using Modis time series data. Remote Sensing of Environment, v. 97, n. 2, p. 137-162, 2005.

SANTOS, J. F.; SOARES, R. V.; BATISTA, A. C. Perfil dos incêndios florestais no Brasil em áreas protegidas no período de 1998 a 2002. Floresta, v. 36, n. 1, p. 93-100, 2006.

SILVA, D. L.; CARNEIRO, M. H. DA S. Biodiversidade, conservação e sustentabilidade no livro didático de Biologia no Brasil. Sustentabilidade em Debate, v. 5, n. 1, p. 98-116. 2014. Disponível em: <https://doi.org/10.18472/ SustDeb.v5n1.2014.9914>. Acesso em: 04 jun. 2020. 
SIMIONI, J. P. D. et al. Caracterização da precipitação pluviométrica na bacia hidrográfica do Rio Ibicuí, RS. Geography Department University of São Paulo, v. 28, n. 0, p. 112, 2015.

SOTILLE, M. E.; BREMER, U. F.; SIMÕES, J. C. Avanço e retração de área glacial no extremo norte da Península Trinity, Antártica, entre 1988 e 2015. Geography Department University of São Paulo, v. 31, p. 72, 2016.

TOMZHINSKI, G. W.; COURA, P. H. F.; FERNANDES, M. DO C. Avaliação da detecção de focos de calor por Sensoriamento Remoto para o Parque Nacional do Itatiaia. Biodiversidade Brasileira, v. 1, n. 2, p. 201-211, 2011.

UNITED STATES GEOLOGICAL SURVEY. Dados Landsat-8, 2017. Disponível em: <https://earthexplorer.usgs.gov/> Acesso em: 1 jun. 2017. 